\title{
From the Seven Wonders of the Ancient World to the UNESCO World Heritage: Political and Economic Aspects of Institutionalised Cultural Preservation
}

\author{
Branka Butina
}

\begin{abstract}
The current paper thematised the institutionalisation of cultural protection and thereby draws a chronological arc from the ancient world wonder catalogue over first modern codifications up to the UNESCO-World Cultural Heritage nomination. The contribution focuses on development and establishment of cultural protective initiatives and programmes in the (right) historical context. By reference to regional specific examples, transformations as well as rivals between national, supranational and individually initiated patterns of action will be shown. Apart from the internationally organised protection of cultural heritage, there is an increasing establishment of new trade systems on the basis of globally operating, national trusts. The commitment of the US-American J. Paul Getty Trust by restoration and conservation of outstanding cultural heritage like the Buddhist Mogao Caves shows exemplarily how the practice of global cultural preservation can become a component of foreign-policy efforts. Among political instrumentalization, economic value added will also be discussed as well as plebiscitary proceedings. This begs, among other, the question of the cultural protective character of privately initiated activities such as the Internet poll about the 'New Seven Wonders of the World' (2000-2007).
\end{abstract}

Key words: world cultural heritage, protection of cultural heritage

\section{Od sedam svjetskih čuda do svjetske baštine UNESCO-a: politički i ekonomski aspekti institucionalizirane zaštite kulture}

Rad se bavi institucionaliziranom zaštitom kulture kronološki prateći nastojanja na tom polju, od popisa sedam svjetskih čuda antike preko prvih modernih sistematizacija sve do nominacija za Listu svjetske kulturne baštine UNESCO-a. U središtu je analize proces osnivanja i razvoja inicijativa za zaštitu kulture u povijesnom kontekstu. Referirajući se na specifične regionalne primjere, prate se transformacija i svojevrsna konkurencija između nacionalnih, nadnacionalnih i individualnih obrazaca djelovanja na tom polju. Osim međunarodno organizirane zaštite kulturne baštine sve je prisutnija i uspostava novih sustava na temelju globalnih i nacionalnih zaklada. Ugovorna obveza američke Zaklade „J. Paul Getty” u zaštiti i obnovi iznimnih kulturnih blaga poput budističke spilje Mogao pokazuje kako praksa globalne zaštite kulture može postati sastavni dio vanjskih politika. Rad se bavi i ekonomskom dodanom vrijednosti kao i plebiscitarnim aktivnostima u očuvanju

Please cite this article as: Butina, B., 2011: From the Seven Wonders of the Ancient World to the UNESCO Wor Heritage: Political and Economic Aspects of Institutionalised Cultural Preservation, Hrvatski geografski glasnik 73(2), 141-154 
globalnih kulturnih elemenata. Postavlja se i pitanje o značaju privatno pokrenutih akcija za zaštitu kulturne baštine, poput internetskoga glasovanja pri izboru „Novih sedam svjetskih čuda" (2000. - 2007.).

Ključne riječi: svjetska kulturna baština, zaštita kulturne baštine

\section{INTRODUCTION}

The hypothesis that the ancient canon of the Seven Wonders of the World can be considered a very early - if not the earliest - testament to supranational cultural preservation, is very tempting: a span of 2300 years could be established, which ranges from the classification of Greek authors of the third and second century before Christ to the ratification of the UNESCO World Heritage Convention in 1972.

The feasibility of such a proposition can, however, only be explored through an analysis of the term "cultural preservation". Proceeding from the definition that cultural preservation encompasses practices of preservation of qualified artefacts, it becomes evident that the term is comprised of an objective and subjective meaning: the objective classification of a cultural asset as especially worthy of preservation goes hand-in-hand with the subjective volition for its protection and preservation.

Cultural generation and cultural preservation are at all times interconnected with the political systems of government and religious thought patterns in which they transpire.

In the following, the artefact as a cultural asset shall be elucidated within the context of its socio-cultural genesis and subsequent transformation.

Cultural preservation is practised in systems that, on the one hand, are defined by their spatial expansion, and on the other through culture-specific contents.

Communication among these systems is effected formally through legal policies, and contextually through the overlapping of divergent concepts of culture.

The following consideration of the institutionalisation of cultural preservation refers to a space not defined by national borders, but by cultural identity: the eastern Mediterranean of the Hellenistic Era - the location of all but one of the Seven Wonders of the Ancient World (the Hanging Gardens of Babylon).

The canon of the Seven Wonders of the World neither implicates selection criteria nor does it particularise on the intentions of the classical authors. Moreover, the denomination of the structures as "Wonders of the World" is ambiguous: admittedly, Latin sources mention "de septem mundi miraculis". Older Greek texts, however, denote these structures precisely not as "thaumata" (marvels, wonders) but as "theamata", which translates into "places of interest" (Ekschmitt 1996, 9).

In contrast, the UNESCO World Heritage Convention of 1972 defines selection criteria, states the purpose of the convention and places the volition to preserve into a supranational 
context (quotation preamble World Heritage Convention): "aspects of cultural heritage that are of extraordinary, universal significance and thus must be preserved as elements of the world heritage of all mankind."

It suggests, therefore, viewing the Seven Wonders of the Ancient World as a catalogue of outstanding structural feats, which itself is orientated towards Greek mainstream culture - a travel guide for wealthy culture elitists as it were (Brodersen 1996, 9). In this respect, the canon of the Seven Wonders of the Ancient World can not yet be considered as a document of supranational cultural preservation of the Classical Age. The supraregional cultural awareness expressed therein, however, can be qualified as a precursor (in nuce) of supranational cultural preservation.

\section{CULTURAL PRESERVATION IN THE MIDDLE AGES}

The catalogue of the Seven Wonders of the World has been updated throughout the Middle Ages. Detached from its original function as a regional guidepost to significant cultural monuments, the term itself has assumed an independent existence as a symbol for the extraordinary and has engendered a myth.

The dominance of the Roman Empire, as well as the proliferation of Christianity, has given rise to its modification. The Coliseum in Rome (80 A.D.) replaces the Colossus of Rhodes; Solomon's Temple supersedes the Statue of Zeus at Olympia (Brodersen 1996, 101f.).

In its most extreme form, this action pattern becomes apparent in the antagonist of cultural preservation, that is, cultural annihilation. Cultural annihilation is not premised on aesthetic value judgements, but delineates a symbolic act of submission (Choay 1997, 81f.f.). Correspondingly, the destruction of the Temple of Artemis in Ephesus by St. Chrysostom in 401 A.D. was religious conflict put into practice.

The main purpose of vandalism during the Cultural Revolution in China (1966 1976), to which hundreds of thousands of extremely valuable artefacts of a history of three thousand years fell victim, was to eradicate the collective memory of imperial China.

The highly symbolic dislocation of marble fragments of Adolph Hitler's Reich Chancellery in Berlin, which was destroyed in 1949, into Soviet war memorials and even into Berlin underground stations (Mittig, 2005), was not meant to annihilate a specific aesthetic design vocabulary, but to symbolise the destruction of National Socialist ideology.

A contrasting action pattern can be deduced from the structural history of France's oldest church - St. Pierre aux Nonnains in Metz ( $4^{\text {th }}$ century A.D. $)$. A Roman secular building, still well discernible today, gradually developed initially into an early mediaeval church, then a military arsenal, a monastery and eventually a forum for contemporary art (Will, 2005). This led to a complex cultural asset, which not only functions as a repository of Metz' city history, but also as a striking testament to a historico-cultural superposition of function.

Cultural preservation and cultural annihilation delimit a space in which complex cultural transformations take place. Herein, genuine cultural assets are modified and directed 
towards new purposes. I propose the not yet academically established term "CULTURAL UTILISATION".

A little-known example of this is the purely utilitarian-motivated dismantling of the burnished limestone casing stones of the Pyramid of Cheops for the construction of bridges and buildings in mediaeval Cairo. This process exemplifies how the discontinuity of cultural self-conception can lead to a loss of volition of cultural preservation.

The rise of Christendom takes place approximately at the same time as the demise of the Roman Empire. The fine-meshed network of ecclesiastical, economically powerful institutions like monasteries and congregations encompassing all of Europe facilitated, for the first time, a supranational practice of cultural protection. This can definitely be seen as an institutionalisation of cultural preservation, although the focus on religious belief denotes an extreme form of selection.

The elimination of artefacts pertaining to non-Christian cultures was the cost of Christian universalism. The smelting of Inca gold by Spanish conquistadores, as an example, not only led to the loss of unique cultural objects, but also the waning of the memory of an advanced regional civilisation.

\section{CULTURAL PRESERVATION IN THE MODERN PERIOD}

From the Renaissance onwards, dominance of clerical cultural preservation was on a steady decline and ended with the secularisation at the turn of the $18^{\text {th }}$ to the $19^{\text {th }}$ century. In search of a symbolic benchmark, the destruction of the Burgundian abbey church in Cluny (1810) suggests a good initial point. At Napoleon's behest, the second largest and most resplendent Christian church ever erected was blasted in an act of unprecedented cultural annihilation, in order to gain building material for the construction of the imperial stables $^{2}$ (Wollasch, 2001).

Although the reconstruction with genuine building materials is not possible, interested parties can, however, experience a tour through the former grandiose structure. A virtual reconstruction was made with the help of fragments, which constitutes an attractive and promising option of cultural preservation. ${ }^{3}$

Nevertheless, the Napoleonic reign also delineates, in the light of political aspects, a caesura in the practise of cultural preservation. It created the prerequisites for the establishment of at least tendentiously democratic states within which early legal policies for the protection of cultural assets in regional and national spaces could be codified - like the first Hessian monument protection act of 1818, as well as the first German monument protection act of 1902 (LfDH, 2003). The first French monument protection act was passed in 1887 and protected classified cultural sites of national importance (Clemen, 1893). The protection of national monuments in the United States traces back to the so-called Antiquities Act of 1906, which served the purpose of protecting prehistoric structures and tools of Native American origin in the western states of the US (Sellars, 2007).

These first national codifications of cultural preservation were ultimately required for the - albeit much later - elevation of the policies of cultural preservation to constitutional 
principles. In contrast to the Federal Republic of Germany, European countries such as Spain, Poland, Sweden and Switzerland have a cultural article nowadays in their respective constitutions, which explicitly refers to the promotion of culture as a governmental endeavour, while retaining the principal division of federal responsibilities. ${ }^{4}$

The European Union explicitly addresses the promotion of culture in Article 151 of the EC contract. The Community supports member states especially in "the preservation and protection of the cultural heritage important to Europe". 5 Surprisingly enough, the Federal Republic of Germany, which to a special degree claims to be a cultural nation of high order, has not managed up until now to enshrine the principles of cultural preservation in the German Constitution, although they were already codified in Article 150 of the Weimar Constitution. ${ }^{6}$

\section{CULTURAL PRESERVATION TODAY}

The prerequisites for the elevation of cultural preservation from a national to an international level were only made possible through the establishment of international conventions. The prime principle among the international community is the equality of states as an expression of their sovereignty.

A transfer of sovereignty rights to international committees - such as UNESCO - is necessary to generate generally mandatory standards. Hence, the core of cultural geography, in consideration of world heritage, is a partial renunciation of national sovereignty. This is, for instance, visible in the dispute over the revocation of world heritage status of the Dresden Elbe Valley.

The entirety of policies, according to which the transfer of rights takes place, as well as their administration and exercise, shall therefore be subsumed under the term institutionalisation.

Culture and institutionalisation initially appear as contradictory terms: whereas culture generally is determined by a free and illimitable unfolding of creational forces, institutionalisation, in contrast, sets spatial, material and temporal limits. Global strategies of cultural preservation are therefore only feasible through interaction of both principles.

Initially international - and now global - cultural preservation was initialised by the Athens Conference in 1931 and the Venice Charter of 1964, as well as the founding of UNESCO (1946) and completed with the passing of the World Heritage Convention (Paris 1971). With 186 participating nations, its degree of execution is surpassed by no other convention in the world.

In April 2006, after lengthy international negotiations, the Convention for the Protection of Immaterial Heritage came into effect as the most recent instrument to supplement the UNESCO World Heritage Convention of 1972. ${ }^{7}$ Whilst the World Heritage Convention has concentrated thus far on clearly defined sites on national territories, the new convention seeks to protect oral traditions, such as dance and song, literature, theatre and rituals. 
These new conventions take into account especially the participating nations that hitherto were only scarcely or not at all featured on the list of the World Heritage Convention. Concurrently, tensions on a national and international level can be decreased by such means (Rössler, 2005). Still, the predominant fraction of certified world heritage is located in Europe (Fig. 1). The new convention could contribute to level the much-cited 'lack of balance' - at any rate to some extent.

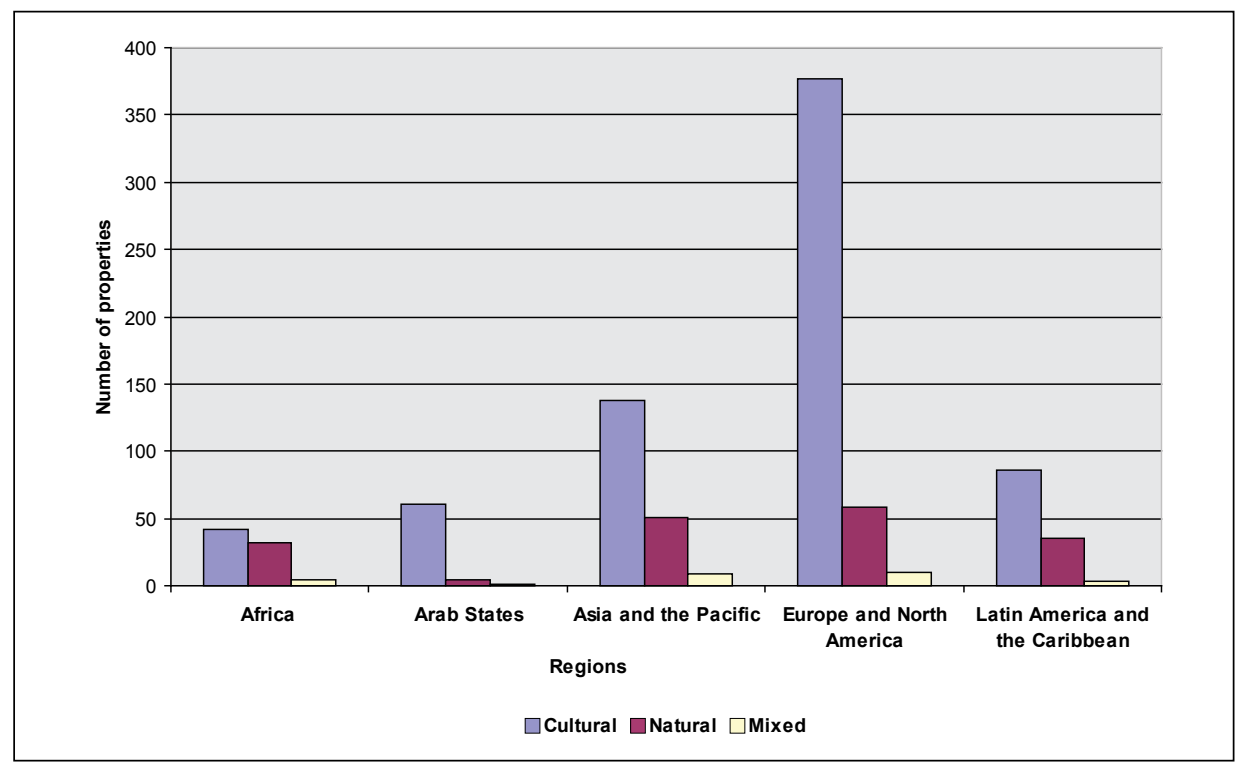

Fig. 1 Number of World Heritage Properties by region

Sl. 1. Popis svjetske kulturne baštine prema regijama

Source: http://whc.unesco.org/en/list/stat (20.09.2010)

The institutionalisation of cultural preservation on the basis of the World Heritage Convention pertains to the proceedings of inclusion of a cultural asset in the World Heritage Roster, as well as the conditions for the preservation of a cultural asset and the formalities for the revocation of a world heritage status. Practical evaluation patterns comply with scientific criteria.

In the course of globalisation, the field of cultural preservation has experienced a transformation of classic evaluation patterns. The interpretation of world heritage shifted from single monuments via ensembles and cultural landscapes to immaterial cultural assets. The most innovative aspect of this new convention is the fact that extraordinary value is no longer a criterion. Instead, the new practices of preservation are inclined towards an "encyclopedisation" of the assets worth preserving. This, in turn, gives way to an abandonment of the original aspect of hierarchisation of the World Heritage Roster.

When considering cultural heritage - whether material or immaterial -in the shape of a matrix influenced by various parameters, such as spatial expansion, utilisation, purpose 
or perception, shifts of meanings and values of cultural assets can be explained exemplarily with regard to their temporal components (Fig. 2).

A process that has had a transformatory effect on the system of cultural preservation is Heritage-ification (Wöhler, 2008): to achieve inclusion into the roster of world heritage, any historical, as well as contemporary structure must be abandoned. Cultural heritage is, through the process of "achronisation", re-valued by imbuing it with symbolic charge and attribution. The international frame of reference of UNESCO relevant to present times liberates locally rooted cultural heritage from its socio-historical context and assigns it a new meaning, which in turn is integrated in a global system of meaning (Fig. 2). The transformed world heritage is experienced as changed. Against this background, the heritage practice can be termed a meaning-making system, within which "outstanding universal value" is generated (May/Saretzki, 2010).

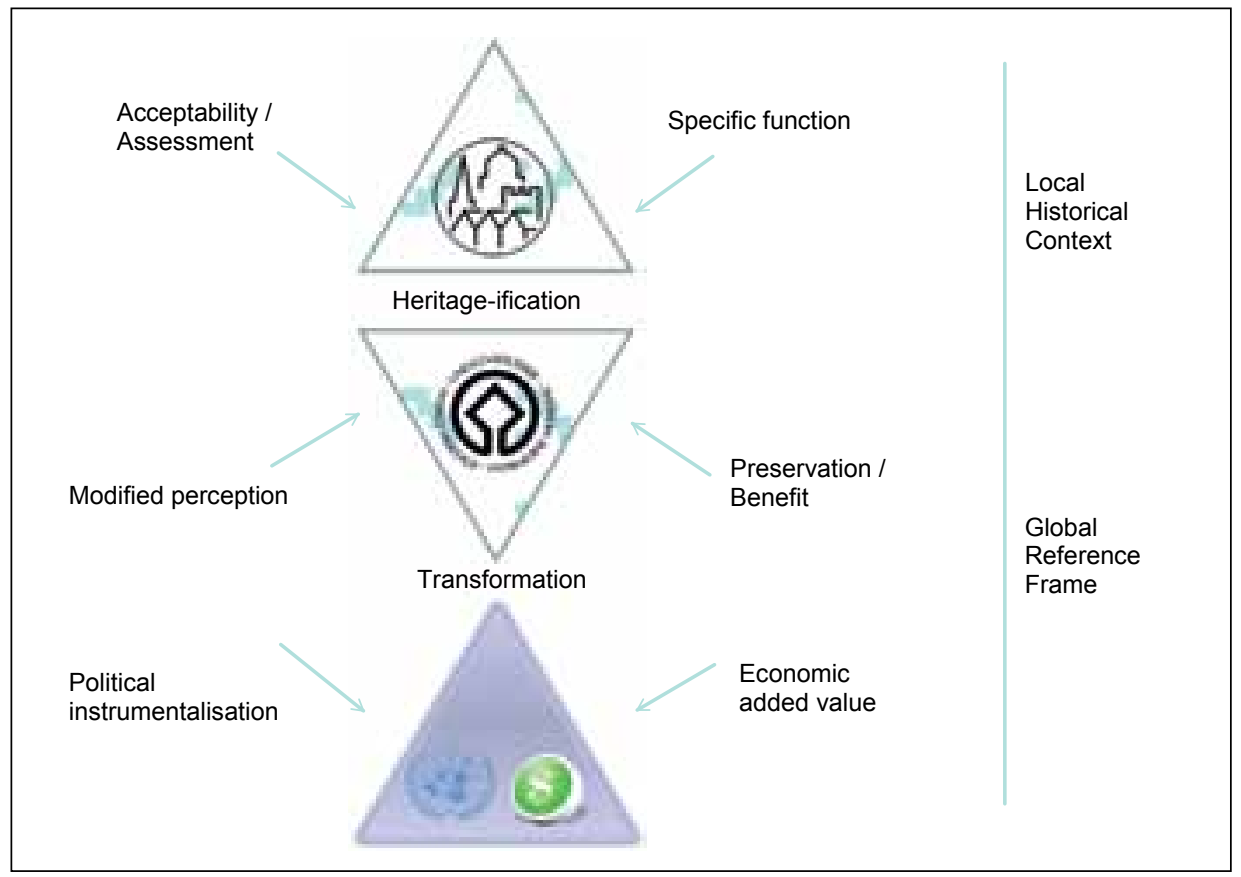

Fig. 2 "Heritage-ification" - Process and influencing variables

(Own construction on the basis of Wöhler, 2008; May/Saretzki 2010)

Sl. 2. Baštinizacija-postupak, varijable i njihov utjecaj

(vlastita ilustracija na temelju Wöhler, 2008.; May/Saretzki, 2010.)

\section{THE UNESCO WORLD CULTURAL HERITAGE - POLITICAL ISSUE OR ECONOMIC RESOURCE?}

When UNESCO committees decide on whether a cultural asset constitutes "unique evidence" or can claim "universal significance", the scientific competence of the predominantly juridically educated policymakers (usually professional diplomats) can not 
Hrvatski geografski glasnik 73/2 (2011.)

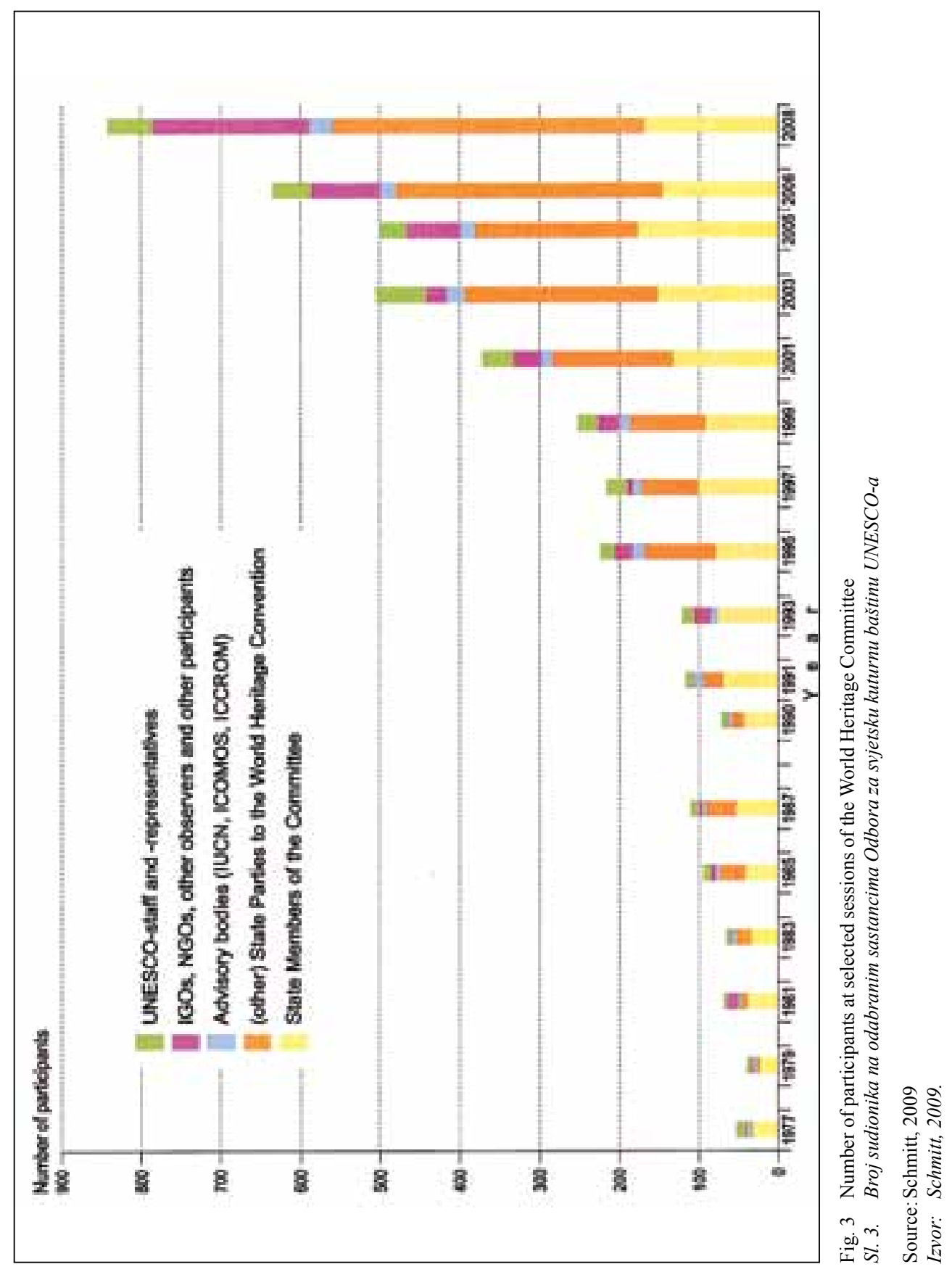


be guaranteed. Therefore, the World Heritage Committee is nowadays mainly staffed by culture experts. Science as a global communicational context objectivises decision-making processes and thus creates transnational liabilities. The primacy of policy is supplanted by the primacy of experts (Fig. 3).

Nevertheless, this transformation is thwarted by a development that emerges from the possibility of commercialisation of certified world heritage sites. Patronisation of tourism and regional skimming of excess profits through culture commercialisation promote action patterns orientated rather to regional and national particular interests than to supranational strategies. There are indications which suggest that, increasingly, the primacy of policy and experts is partially subverted by commercial strategies.

The agency of non-governmental organisations, which are comprised of experts not subject to directives, who promote objectivity through their advisory function and substantially contribute to the international credibility of world heritage committees, acts as a corrective for these developments. To mention a few: the International Council on Monuments and Sites (ICOMOS), Warsaw, 1965, and the International Centre for the Study of the Preservation and Restoration of Cultural Property (ICCROM), Rome, 1956.

Another corrective arises out of the World Heritage Convention itself. According to Article 174 of the directives, any citizen, who perceives a cultural asset as endangered, can apply directly to the World Heritage Committee by filing a personal complaint and thereby prompt supranational actions. This little-known but very effective instrument bypasses the conventional channels of municipalities, federal state authorities, ministries of education and cultural affairs, committees of the ministries of education and cultural affairs, ministries of foreign affairs, and ambassadors to UNESCO and the World Heritage Committee. Violations of the convention are unlikely to produce self-indictment of member states, thus this legal institution of quasi-plebiscitary character gains considerable significance as a "trigger" for supranational activity within the scope of the Charter.

Alongside the internationally organised cultural preservation by conventions, gradually new systems of action establish themselves on the basis of globally operating national foundations. The US-American Paul Getty Foundation and its spectacular commitment to the salvation of the Buddhist Mogao Grottoes in China and the restoration of the sepulchral of Tutankhamun in Egypt, for example, shows how supranational and bilateral systems of cultural preservation overlap. Contrary to UNESCO, these foundations do not operate on the basis of codified international law, but conclude contracts of co-operation with benefited nations. The foundation provides funding and experts if there is need on a communal level - characteristically a problem for many threshold nations. In this way, transnationally practised cultural preservation is employed as an indirect strategic means offoreign policy.

The institutionalisation of cultural preservation has generated high effectiveness and global commitment with international conventions and the deployment of experts. It is, however, noteworthy to consider that a similarly globally active force may weaken or subvert these effects.

There is evidence that private capital in hitherto unknown dimensions is utilised to invest in significant cultural assets with the aim of profit maximisation. On the $5^{\text {th }}$ of 
December, 2007, Sotheby's sold a 5000-year old statuette of a limestone lioness, eight centimetres tall, which was excavated near Baghdad for US\$ 57.2 million. ${ }^{8}$ With the buyer remaining anonymous, it can be assumed that, according to the opinion of experts, a significant artefact is being withheld from the public and is being kept in a safety deposit box as high-profit stock. Strategies such as this, for which I propose the term "COMMERCISM", deprive the world community of significant cultural values, which is irreconcilable with the principles of the World Heritage Convention. If extraordinary cultural feats constitute a collective heritage of all of mankind, the presence of significant artefacts in museums must be guaranteed.

The charisma of the wording of the "Seven Wonders of the World" prevails unabated, even after more than 2000 years, and transports the term effortlessly into the global space of modernity. This is exemplified by an Internet campaign (2000-2007), where 60 million people from all over the world voted for the "New Seven Wonders of the World", with surprising results: the official new Seven Wonders are comprised of Machu Picchu (Peru), the Great Wall of China, the Coliseum (Italy), Christ the Redeemer (Brazil), Chichen Itza (Mexico), the Taj Mahal (India) and Petra (Jordan). ${ }^{9}$ Worthy of note: the oldest of the Seven Wonders of the World (the archetype) - the pyramids in Egypt - are no longer part of the canon.

The new election of Wonders of the World sites also implicates a shift in spatial dimension. While the Seven Wonders of the Ancient World are, with one exception (The Hanging Gardens of Babylon), situated in the cultural region of the Mediterranean, the new Seven Wonders of the World are scattered on the continents of Asia and America, in each case three world wonder sites, with only the Coliseum in Rome still representing the western cultural region. The project shows how plebiscitary procedures can enter the domain of supranational cultural evaluation through the application of modern communication technology. The project is declared the world's first global democratic vote by its proponents.

Unsurprisingly, the Internet campaign was met with vivid opposition by UNESCO committees, who saw their monopoly of global cultural preservation by experts compromised. ${ }^{10}$ Apart from this, the method of polling does not meet the criteria of scientific rigour - Which media were responsible for the transportation of the survey? Who had access to the Internet? - and thus the whole campaign seems questionable.

In a period, when 911 UNESCO cultural heritage sites have already been designated (effective 2010, see Fig. 4), it makes little sense to condense this portfolio into a canon of seven wonders. The statutory principle of the preservation of cultural diversity of the UNESCO Charter would be compromised and lead to a politically initiated competition for prestigious sites on the roster of the Seven Wonders. 


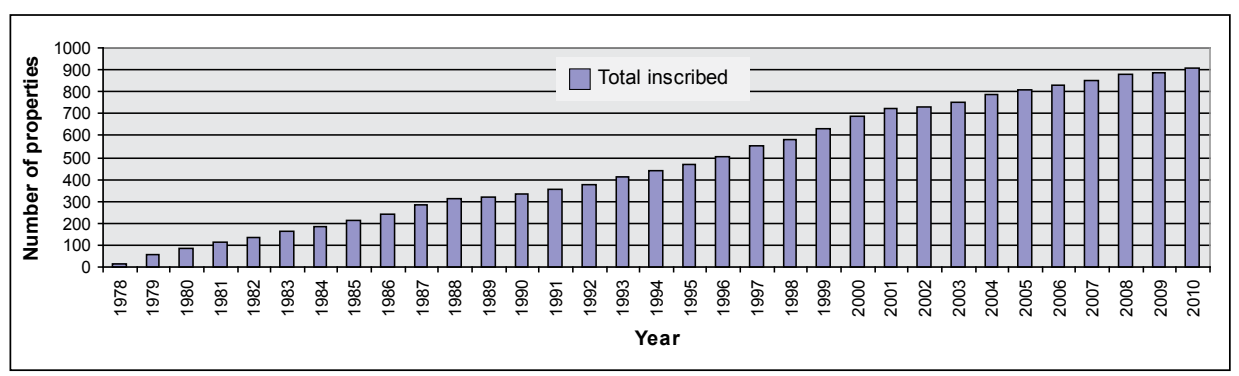

Fig. 4 Total number of properties inscribed per year (cumulative)

Sl. 4. Ukupni broj upisanih elemenata svjetske kulturne baštine godišnje (kumulativno)

Source: http://whc.unesco.org/en/list/stat (20.09.2010)

Izvor: http://whc.unesco.org/en/list/stat (20.09.2010)

\section{CONCLUSION}

Concluding, the focus shall be put on the perspectives of international cultural preservation:

Cultural preservation has undergone many transformations in its history of more than 2000 years and neither today can the status quo of a global consensus on the principles of the UNESCO Charter be considered final. The comprehensible wish of all nations to be included on the World Heritage Roster has lead, on the one hand, to an almost inflationary increase in prized artefacts, with a parallel modification of the original strict, hierarchically oriented cultural evaluation into an encyclopaedic inventory of highly different cultural values. On the other hand, it is evident that, more and more, capital streams exert influence on the system of cultural preservation, with the result of particular interest in competition with global concepts.

A deciding factor for the future of the world heritage project will be the establishment of a balance between universal entitlement and particular interests. A modern, indicatory conception of cultural preservation can no longer limit itself nowadays to classic practices of memory, protection and care, but has to end in an interdisciplinary - politically as well as economically - dialogue of all nations, with the long-term aim of making the decisive step from the globalised world towards a world community. 


\section{NOTES}

1 Preamble to UNESCO World Heritage Convention

2 Haras National

3 http://www.cluny-numerique.fr/ (13.09.2010); NZZ Online, 29.09.2010

4 interim report of the Enquete-Kommission 2005

5 Article 167 AEUV, ex-Article 151 EGV

6 According to Dr. Birgitta Ringbeck, the German representative at UNESCO, it is "an incredible scandal in cultural policy" (Ringbeck, 2006)

7 UNESCO Convention for the Safeguarding of Intangible Cultural Heritage

8 http://www.sothebys.com, 10.10.2010; Schulz, 2008

9 http://www.new7wonders.com/de/ 28.09.2010

10 Spiegel Online 08.07.2007

\section{REFERENCES}

Brodersen, K., 1996: Die Sieben Weltwunder. Legendäre Kunst- und Bauwerke der Antike. München.

Choay, F., 1997: Das architektonische Erbe, eine Allegorie. Geschichte und Theorie der Baudenkmale. Braunschweig. Wiesbaden.

Clemen, P., 1893: Die Denkmalpflege in Frankreich. in: Zeitschrift für Bauwesen, Jg. 48, 489-538.

Deutscher Bundestag (ed.), 2005: Kultur als Staatsziel. Zwischenbericht der Enquete- Kommission "Kultur in Deutschland". Drucksache 15/5560 vom 01.06.2005. www.kulturrat.de/dokumente/ Bundestagsdrucksachen/1505560.pdf

Ekschmitt, W., 1996: Die Sieben Weltwunder. Ihre Erbauung, Zerstörung und Wiederentdeckung. Mainz am Rhein.

Frank, K. S., 1981: Cluny. in TRE 8, 126-132.

Landesamt für Denkmalpflege Hessen (ed.), 2003: 100 Jahre Denkmalschutzgesetz in Hessen. Geschichte, Bedeutung, Wirkung. Stuttgart.

May, C., Saretzki, A., 2010: Bewahren - Vermarkten. Welterbetourismus zwischen lokalem Erbe und globaler Vermarktung. in Egger, R., Herdin, Th. (ed.) Tourismus im Spannungsfeld von Polaritäten. Wien, Münster, 24-38.

Mittig, H.-E., 2005: Marmor der Reichskanzlei. in Bingen, D./Hinz, H.-M. (ed.), Die Schleifung. Zerstörung und Wiederaufbau historischer Bauten in Deutschland und Polen. Wiesbaden, 174-187.

Ringbeck, B., 2006: Die Welterbekonvention - Rechtliche Rahmenbedingungen und Verpflichtungen. Vortrag anlässlich einer ICOMOS-Tagung zum Weltkulturerbe in Deutschland. Beiträge unter: http://193.175.110.9/hornemann/german/epubl_detail_tagungen10_148.php

Rössler, M., 2005: Weltkulturerbe und Globalisierung: Vom Weltwunder zum Erbe der Menschheit. in Höhler, I./Schröder, S. (ed.): Welt-Räume: Geschichte, Geographie und Globalisierung seit 1900. Frankfurt a. M., 235-257.

Schmitt, Th., 2009: Global Cultural Governance. Decision-Making Concerning World Heritage between Politics and Science. in Erdkunde, Vol. 63, No. 2, 103-121. 
From the Seven Wonders of the Ancient World to the UNESCO World Heritage:

Political and Economic Aspects of Institutionalised Cultural Preservation

Schulz, M., 2008: Helden auf dem Prüfstand. in Der Spiegel, Heft Nr. 3, 112-115.

Sellars, R. W., 2007: A Very Large Array: Early Federal Historic Preservation — The Antiquities Act, Mesa Verde, and the National Park Service Act. Published by the University of New Mexico School of Law, National Resources Journal, Vol. 47, No 2.

UNESCO (ed.), 1972: Convention Concerning the Protection of the World Cultural and Natural Heritage Adopted by the General Conference at its Seventeenth Session, Paris.

UNESCO (ed.), 2006: Convention for the Safeguarding of the Intangible Cultural Heritage, Paris.

Will, M., 2005: Die ehemalige Abteikirche St. Peter zu Metz und ihre frühmittelalterlichen Schrankenelemente. (Bonner Beiträge zur vor- und frühgeschichtlichen Archäologie 3). Bonn.

Wöhler, Kh., 2008: Heritagefication: Zur Vergegenwärtigung des Kulturerbes. in Luger, K. ; Wöhler, Kh. (ed.), 2008: Welterbe und Tourismus. Schützen und Nützen aus einer Perspektive der Nachhaltigkeit. Innsbruck. 43-58.

Wollasch, J., 2001: Cluny - Licht der Welt. Aufstieg und Niedergang der klösterlichen Gemeinschaft. Düsseldorf.

\section{SOURCES}

Deutsches UNESCO - Portal

Übereinkommen zum Schutz des Kultur- und Naturerbes der Welt:

http://www.unesco.de/welterbekonvention.html?\&L=0 (29.10.2010).

Europäische Kommission

http://ec.europa.eu/culture/key-documents/doc1841_en.htm (20.10.2010).

New 7 Wonders of the World

http://www.new7wonders.com/de/ (28.09.2010).

NZZ Online

http://www.nzz.ch/nachrichten/kultur/aktuell/cluny_leuchtet_1.7731838.html

Werner Bloch, Artikel vom 29.09.2010. "Cluny leuchtet"

Projekt Cluny

http://www.cluny-numerique.fr/ (13.09.2010).

Sotheby's Art Auction House

The Guennol Lioness

http://www.sothebys.com/app/live/lot/LotDetailPrintable.jsp?lot_id=159415093 (10.10.2010).

\section{Spiegel Online}

Article 08.07.2007 "Umstrittene Abstimmung"

http://www.spiegel.de/wissenschaft/mensch/0,1518,493158,00.html (10.09.2010).

World Heritage List Statistics

http://whc.unesco.org/en/list/stat (20.09.2010)

World Heritage List Statistics

http://whc.unesco.org/en/list/stat (20.09.2010) 
Hrvatski geografski glasnik 73/2 (2011.)

Received (Primljeno): 2011 - 05 - 11

Accepted (Prihvaćeno): 2011 - 12 - 21

\section{Branka Butina}

Department of Regional Geography

University of Passau

D-94032 Passau, Innstraße 40

branka.butina@uni-passau.de 